\title{
Joint Associations of Daily Sitting Time and Leisure-Time Physical Activity with Body Fat Distribution Among US Adults, NHANES 2011-2018
}

Jingwen Liao ( $\square$ liaojw@gzsport.edu.cn )

Guangzhou Sport University

\section{Min Hu}

Guangzhou Sport University

Kellie Imm

University of Southern California

Clifton Holmes

Washington University School of Medicine

Chao Cao

Washington University School of Medicine

\section{Lin Yang}

Alberta Health Services

\section{Research Article}

Keywords: Sitting time, Physical activity, Body fat distribution, Adults

Posted Date: February 14th, 2022

DOI: https://doi.org/10.21203/rs.3.rs-1348807/v1

License: (c) (i) This work is licensed under a Creative Commons Attribution 4.0 International License. Read Full License 


\section{Abstract}

Background: Prolonged sitting and reduced physical activity lead to low energy expenditures. However, little is known about the impact of daily sitting time jointly with physical activity on body fat distribution.

Methods: We investigated the independent and joint associations of daily sitting time and physical activity with body fat distribution among through a cross-sectional analysis of US nationally representative data from the National Health and Nutrition Examination Survey 2011-2018 among adults aged 20 years or older. Daily sitting time and leisure-time physical activity (LTPA) were self-reported using the Global Physical Activity Questionnaire. Body fat distribution (total and trunk fat percentage) was determined via dual X-ray absorptiometry.

Results: Among 10,808 adults (weighted population: 127,746,295; mean [SE] age, 39.4 [0.2] years; 5371 [49.7\%] females), about $58.8 \%$ of adults spent $\geq 6 \mathrm{~h} / \mathrm{d}$ sitting; more than half reported no LTPA (inactive) or $<150$ minutes/week LTPA (insufficiently active) with only $40.6 \%$ reported $\geq 150$ minutes/week LTPA (active) in the past week. After adjusting for sociodemographic and lifestyle factors, prolonged sitting time and low levels of LTPA were associated with higher total and trunk fat percentages in both sexes. In particular, sitting $>8 \mathrm{~h} / \mathrm{d}$ was associated with $2.03 \%(95 \% \mathrm{Cl}, 1.16$ to 2.90$)$ and $1.91 \%(95 \% \mathrm{Cl}, 1.11$ to 2.70$)$ increases in trunk fat in male and female adults, respectively, after accounting for LTPA. When stratifying by LTPA, the association between daily sitting time and body fat percentages appeared to be stronger in those who are inactive/insufficient active. In the joint analyses, inactive/insufficiently active adults who reported sitting $>8 \mathrm{~h} / \mathrm{d}$ had the highest total (male: $3.79 \%[95 \% \mathrm{Cl}, 2.75$ to 4.82]; female: $3.99 \%$ [95\%, 3.09 to 4.88]) and trunk body fat percentages (male: $4.07 \%$ [95\% $\mathrm{Cl}, 2.95$ to 5.19]; female: $4.21 \%$ [95\% Cl, 3.09 to 5.32$]$ ) compared with those who were active and sitting $<4 \mathrm{~h} / \mathrm{d}$.

Conclusions: Prolonged daily sitting time was associated with increased body fat among US adults. The higher body fat associated with $6 \mathrm{~h} / \mathrm{d}$ sitting may not be offset by achieving recommended levels of physical activity.

\section{Introduction}

Sedentary behavior, defined as any waking behavior with energy expenditure $\leq 1.5$ metabolic equivalents in a sitting, reclining, or lying posture,(1) is becoming increasingly prevalent in the population and associated with a range of negative health effects.(2) The World Health Organization (WHO) updated the 2020 guidelines on physical activity and sedentary behavior, and for the first time recommend limiting the amount of sedentary time and replacing sedentary behaviors with any physical activity for health benefits.(3) However, the joint effects of sedentary time and physical activity on health outcomes is limited, hence creating a critical evidence gap to inform quantitative guidelines on sedentary time.

Excess fat in adults, particular abdominal fat, is associated with impaired metabolic health and premature death.(4-6) Prolonged sitting and reduced physical activity results in a lack of muscle contractions and low energy expenditure, leading to weight gain and obesity. $(7,8)$ Previous studies suggested that prolonged sitting was positively associated with BMI and waist circumference as markers of obesity,(9) but inconsistently associated with body fatness and fat accumulation. $(9,10)$ Few studies have used a validated and accurate measure of body fat distribution, dual X-ray absorptiometry (DXA), and investigated the impacts of prolonged sitting on regional fat accumulation, particularly at the population level.(10-12) Moreover, the evidence is limited on joint association of sedentary behavior and physical activity with body fat distribution.

To address these knowledge gaps, the present study aimed to investigate the independent and joint associations of daily sitting time and leisure-time physical activity (LTPA) with DXA-measured body fat distribution among a 
nationally representative sample of US adults.

\section{Methods}

\section{Study population}

We obtained data from the National Health and Nutrition Examination Survey (NHANES), a continuous survey using a cross-sectional, stratified, multistage probability sampling method to obtain a representative sample of the US population every 2 years since 1999. All NHANES protocols were approved by the ethics review board of the US National Center for Health Statistics and written informed consent was provided by each participant. Detailed descriptions of the survey have been published elsewhere. $(2,13,14)$ In the present study, adults $\geq 20$ years old in four NHANES cycles (2011-2012, 2013-2014, 2015-2016, 2017-2018) with complete information on self-reported daily sitting time and LTPA and whole body DXA measured fat distribution were included. $(2,15)$

\section{Daily Sitting Time and Leisure-Time Physical Activity}

Self-reported time spent on daily sitting and weekly LTPA were based on respondent-level interviews using the Global Physical Activity Questionnaire (GPAQ).(2,16) Participants were asked to recall "On a typical day, how much time do you usually spend sitting at school, at home, getting to and from places, or with friends including time spent sitting at a desk, traveling in a car or bus, reading, playing cards, watching television, or using a computer (except for time spent sleeping)?" Responses were converted to hours per day and further categorized into: 0 to $<4,4$ to $<6,6-8$ and $\geq 8 \mathrm{~h} / \mathrm{d}$ according to recent studies $(17,18)$. The total time spent on LTPA was calculated as minutes of moderate-and vigorous-intensity recreational activities plus twice the minutes of vigorous recreational activities per week as reported. $(19,20)$ According to the 2018 Physical Activity Guidelines for American adults: people without any LTPA, with LTPA $>0$ minutes but $<150$ minutes/week, and with LTPA $\geq 150$ minutes/week in the past week were classified as inactive, insufficiently active and sufficiently active, respectively. $(19,20)$

\section{Measurement of Fat Distribution}

Whole body fat distributions were determined by DXA scans using a Hologic QDR-4500A fan-beam densitometer by certified radiology technologists in the NHANES mobile examination center. Hologic Discovery software 12.1 was used to analyze the DXA exams and provided the body composition data. Fat percentages for total body (including the head, limbs, and trunk area) and trunk (only the trunk area) were derived to measure the magnitude and distribution of body fat.

\section{Assessment of Covariates}

The covariates included sociodemographic data (age, sex, race/ethnicity, education attainment, and family poverty ratio), lifestyle behaviors (smoking status, alcohol use, total energy intake, and healthy eating index-2015 [HEI-2015]), and chronic conditions (hypertension, hypercholesterolemia, history of diabetes, history of cardiovascular diseases, history of cancer, and depression). Race/ethnicity was categorized as non-Hispanic White, non-Hispanic Black, Hispanic, and Other. Education attainment was categorized as less than high school diploma (<high school), high school graduate, and some college graduate or more (>high school). Family poverty ratio was defined as the ratio of family income to the Federal Poverty Level and categorized as $<1.30,1.30-3.49$, and $\geq 3.50$. Total energy intake and HEI-2015 were derived from a 24-h dietary interview. HEI-2015 is a measure for assessing dietary quality and aligns with the Dietary Guidelines for Americans (21); HEl-2015 scores range from 0-100, with higher scores reflecting better diet quality. 
Hypertension was determined by participants receiving a diagnosis from a health professional or NHANESmeasured blood pressure greater than or equal to $130 \mathrm{~mm} \mathrm{Hg}$ systolic or greater than or equal to $80 \mathrm{~mm} \mathrm{Hg}$ diastolic. Hypercholesterolemia was determined by participants receiving a diagnosis from a health professional or NHANESmeasured total cholesterol level greater than or equal to $240 \mathrm{mg} / \mathrm{dL}$ (to convert to millimoles per liter, multiply by 0.0259). History of chronic diseases (diabetes, cardiovascular disease [CVD], and cancer) was determined by participants receiving these diagnoses from health professionals or if participants were instructed to take prescribed medications for these conditions. Depression was assessed using the Patient Health Questionnaire (PHQ-9) and individuals with PHQ-9 scores $\geq 10$ were considered as having major depression.(22)

\section{Statistical analysis}

Following the NHANES analytic guidelines, all analyses accounted for the unequal probability of selection, oversampling of certain subpopulations, and nonresponse adjustments to ensure nationally representative estimates. $(2,13)$ Sample sizes and weighted percentages were calculated according to participants' characteristics and sex. Multivariable weighted linear regression models were applied to estimate $\beta$-coefficient and $95 \%$ confidence intervals (Cls) for the association of daily sitting time and LTPA with total and trunk fat percentages. Final-stage multivariable models were adjusted for age, sex, race/ethnicity, education attainment, family poverty ratio, smoking status, alcohol use, and HEI-2015, hypertension, hypercholesterolemia, history of diabetes, CVD, and cancer and depression. To examine joint associations, participants were classified based on daily sitting time and LTPA to estimate $\beta$-coefficient and $95 \%$ confidence intervals (Cls) using multivariable linear regression models adjusting for the same set of covariates. All analyses were conducted separately among female and male due to the biological difference in body composition. Multiple datasets were aggregated using SAS 9.4 (SAS Institute, North Carolina, US) and all statistical tests were done using Stata, version 16.0 (Stata Corp. LLC). Statistical tests were two-sided and statistical significance was set at $p<0.05$.

\section{Results}

A total of 10,808 adults (weighted population: 127,746,295; mean [SE] age, 39.4 [0.2] years; 5371 [49.7\%] females) was included and participant characteristics were presented by sex in Table 1 . About $54.6 \%$ of adults spent $\geq 6 \mathrm{~h} / \mathrm{d}$ sitting, while $40.6 \%$ reported no LTPA (inactive), 16.1\% reported < 150 minutes/week LTPA (insufficiently active) and $43.3 \%$ reported $\geq 150$ minutes/week LTPA (active) in the past week.

\section{Daily Sitting Time with Body Fat Distribution}

Prolonged daily sitting time was associated with greater total and trunk fat percentage in both males and females after adjusting for sociodemographic and lifestyle factors and chronic conditions (Table 2). Specifically, females and females who spent more than $8 \mathrm{~h} / \mathrm{d}$ sitting had $1.91 \%(95 \% \mathrm{Cl}, 1.11-2.70 \%)$ and $2.03 \%(95 \% \mathrm{Cl}, 1.16-2.90 \%)$ higher trunk fat, respectively, compared with those spent $<4 \mathrm{~h} / \mathrm{d}$ sitting. A significant dose-response relationship exhibited between daily sitting time and body fat percentage, such that each $1 \mathrm{~h} / \mathrm{d}$ increase in daily sitting time was associated with $0.23 \%(95 \% \mathrm{Cl}, 0.14-0.31 \%)$ and $0.22 \%(95 \% \mathrm{Cl}, 0.14-0.30 \%)$ higher trunk fat among females and males, respectively.

\section{LTPA with Body Fat Distribution}

Being physical active, even at an insufficient level, was associated with lower both total and trunk fat percentages (Table 2). Males and females engaging in sufficient LTPA tended to have lower trunk fat percentages compared with those inactive (female: $-2.26 \%$; $95 \% \mathrm{Cl},-2.96--1.57 \%$; male: $-2.12 \%$; $95 \% \mathrm{Cl},-2.71--1.52 \%$ ) after adjusting for 
sociodemographic factors, lifestyle behaviors, and health conditions. Among females, those engaged in insufficient LTPA also had lower total fat $(-0.55 \%$; $95 \% \mathrm{Cl},-1.05--0.05 \%)$ than those inactive in the multivariable model, but this association was not observed for trunk fat.

\section{Joint Associations of Daily Sitting Time and LTPA with Body Fat Distribution}

In the stratified analysis by LTPA, prolonged daily sitting time was associated with higher total and trunk fat among adults who were physically active and inactive/insufficiently active (Table 3). Among females and males who were physical active, sitting $>8 \mathrm{~h} / \mathrm{d}$ was associated with $1.65 \%(95 \% \mathrm{Cl}, 0.44$ to 2.87$)$ and $1.71 \%(95 \% \mathrm{Cl}, 0.73$ to 2.70$)$ higher trunk fat percentages, respectively, comparing to sitting $<4 \mathrm{~h} / \mathrm{d}$. Also, among adults who were inactive/insufficiently active, sitting $>8 \mathrm{~h} / \mathrm{d}$ was associated with $1.86 \%(95 \% \mathrm{Cl}, 0.92$ to 2.81$)$ and $2.24 \%(95 \% \mathrm{Cl}, 1.04$ to 3.43 ) higher trunk fat percentages for females and males, respectively, comparing to sitting $<4 \mathrm{~h} / \mathrm{d}$.

In the joint analyses, total and trunk fat percentages increased from the most active group (sufficiently active and sitting $<4 \mathrm{~h} / \mathrm{d}$ ) to the least active group (insufficiently active/inactive and sitting $>8 \mathrm{~h} / \mathrm{d}$ ) (Table 4 and Figure 1). In the least active group, females and males had 3.99\% (95\% Cl, 3.09 to 4.88$)$ and 3.79\% (95\% $\mathrm{Cl}, 2.75$ to 4.82$)$ higher total fat percentages and $4.21(95 \% \mathrm{Cl}, 3.09$ to 5.32$)$ and $4.07 \%(95 \% \mathrm{Cl}, 2.95$ to 5.19$)$ higher trunk fat percentages, respectively, comparing to the most active group. Notably, the higher total and trunk fat percentages comparing to the least active group indicated statistical significance starting from the combination of sufficiently active and 6-8 h/d sitting time.

\section{Discussion}

In this nationally representative sample of US adults, about $2 / 3$ of adults spent $\geq 6 \mathrm{~h} / \mathrm{d}$ sitting, and more than half reported not achieving 150 minutes/week LTPA. In both females and males, prolonged daily sitting time was associated with higher total and trunk fat percentages, independent of LTPA levels. In the joint analysis, combinations of prolonged sitting and low LTPA were associated with significantly increased total and trunk body fat percentages. Of all groups, insufficiently active/inactive adults with $>8 \mathrm{~h} / \mathrm{d}$ sitting had the highest body fat percentages. Achieving physical activity guideline at $>150$ minutes/week LTPA does not appear to offset the negative effects of $\geq 6 \mathrm{~h} / \mathrm{d}$ sitting on body fat.

To our knowledge, this is the first study to investigate the independent and joint association of sitting time and LTPA with body fat distribution in a nationally representative sample of US adults. The association between sedentary behaviors and measures of adiposity (i.e. body weight, BMI, or waist circumference) has been examined with inconsistent findings.(9) The negative effects of sedentary behavior on health calls for more accurate and direct measurement of fat accumulation among large populations. Previous study based on US adults sample using DXA only suggested that avoiding sedentary behavior (measured by accelerometer) could lower the incidence of obesity in adults when considering LTPA but did not provide dose-response evidence.(11) Consistently, association of the objectively measured sedentary behavior with fat accumulation by DXA was only observed in total body fat percentage (after adjustment for LTPA) but not categorical obesity or overweight among US adults.(12) More accurate results based on magnetic resonance imaging (MRI) but from small sample size (type 2 diabetes individuals) suggested that accelerometer measured sedentary time might have an independent association with heart, liver, and visceral fat, and every 30 min increase on sitting was related to higher visceral fat.(10) However, none of previous studies considered the joint association of sedentary behavior and physical activity with adiposity. This is important because despite that sedentary behavior has been associated with increased all-cause mortality risk among adults, physical activity could offset this detrimental effect of prolonged sitting.(17, 18,23$)$ That is to say, achieving $\geq 150$ 
min/week LTPA could attenuate the elevated all-cause mortality risk due to prolonged sitting to null. The joint association of sitting and physical activity has been determined with other health outcomes including incident CVD, (24) cardio-metabolic health,(25) all-cause mortality,(26) and cancer survival.(27) Using a US nationally representative sample, the present study systematically evaluated the independent and joint associations of total sitting time and LTPA with body fat distribution. A notable dose-response association of total sitting time with total and trunk fat was observed and this association exhibited not only in adults engaging in $<150 \mathrm{~min} /$ week LTPA but also in those achieving $150 \mathrm{~min} /$ week LTPA.

The mechanisms underlying the associations are largely unknown. At the lower end of the bodily movement continuum, large amounts of sedentary time and insufficient physical activity involve reduction of muscle activation, which leads to decreased energy expenditure.(28) Studies indicated that breaking prolonged sedentary behaviors could lead to weight loss. $(7,29)$ Localized accumulation of adipose tissue in the abdominal area (trunk) has been reported to be the best correlate of dyslipidemia seen in the metabolic syndrome,(30) and this link may be explained by excess free fatty acid release, impaired carbohydrate oxidation and muscle glucose storage, reduced hepatic insulin clearance, and elevated triglycerides.(31) As physical activity is a major determinant of body composition (reflected by fat-free mass) and only partly contributes to accumulation of fat in aging adults,(32) sedentary behaviors may also play an important role in fat accumulation. Other hypothesized biologic mechanisms suggest that sedentariness may have involved specific molecular responses, which contribute to poor lipid metabolism through suppressing skeletal muscle lipoprotein lipase activity.(33) It is thus possible that prolonged time on sitting, if these associations are causal, might be a critical driver to metabolic derangement, which manifest in excess accumulation of fat in the abdominal area (mainly as visceral fat).

The new 2020 WHO Global Guidelines on Physical Activity and Sedentary Behavior underscore promoting physical activity among adults, and for the first time include the recommendation of sedentary behaviors but without specific threshold due to limited quantified evidence for better health outcomes.(3) The present study suggested a doseresponse association between total sitting time and body fat percentage. The significant increased body fat percentage (total and trunk) was observed starting at 6-8 h/d of sitting among adults who achieved at least 150 $\mathrm{min} /$ week LTPA, but with any amount of sitting for those engaged in $<150 \mathrm{~min} /$ week LTPA. Inactive or insufficiently active adults who spent $>8 \mathrm{~h} / \mathrm{d}$ sitting tended to have the highest percentage of body fat. Our results agree with a review that suggested above 6-8 h/d of total sitting (self-reported) was a threshold of increased risk of both all-cause and cardiovascular disease mortality after adjustment for physical activity.(34)

\section{Strength and limitation}

The study has several strengths. It included a large US nationally representative sample of adults with the gold standard measurement of body fat distribution. Further, we examined the joint effects of sitting time and physical activity on body fat, which addresses the evidence gaps to inform quantitative guidelines on limiting sedentary behavior. One limitation is the self-reported measure on daily sitting and LTPA.(35) Additionally, this is an observational design using cross-sectional study and cannot infer the directional causality; further research using longitudinal data is required to elucidate the causal effect of sedentary behaviors on body adiposity.

\section{Conclusion}

In this nationally representative sample of US adults, the combination of prolonged sitting and a lack of PA was associated with higher total and regional body fat. The higher body fat associated with $6 \mathrm{~h} / \mathrm{d}$ sitting may not be offset by achieving $>150 \mathrm{~min} /$ week physical activity. 


\section{Abbreviations}

NHANES: National Health and Nutrition Examination Survey; LTPA: leisure-time physical activity; Cl: Confidence interval; SE: Standard error; DXA: Dual X-ray absorptiometry; WHO: World Health Organization; GPAQ: Global Physical Activity Questionnaire; HEl-2015: Healthy eating index-2015; CVD: cardiovascular disease; PHQ: Patient Health Questionnaire; BMI: Body mass index; MRI: Magnetic resonance imaging.

\section{Declarations}

Ethics approval and consent to participate

All NHANES protocols were approved by the ethics review board of the US National Center for Health Statistics and written informed consent was provided by each participant.

Consent for publication

Not applicable

Availability of data and materials

The datasets generated and/or analyzed during the current study are available in the NHANES repository: [https://wwwn.cdc.gov/nchs/nhanes/default.aspx].

Competing interests

The authors have no conflicts to disclose.

Funding

None

Authors' contributions

$\mathrm{J}$ Liao, C Cao, and L Yang had full access to all the data in the study and take responsibility for the integrity of the data and the accuracy of the data analysis. Study concept and design: J Liao, C Cao, and L Yang. Acquisition, analysis or interpretation of data: all coauthors. Drafting of the manuscript: J Liao, M Hu, C Cao, and L Yang. Critical revision of the manuscript for important intellectual content: all authors. Statistical analysis: J Liao and C Cao. Administrative, technical, or material support: J Liao. Study supervision: J Liao, C Cao, and L Yang. All authors read and approved the final manuscript.

Acknowledgements

Not applicable

\section{References}

1. Tremblay MS, Aubert S, Barnes JD, Saunders TJ, Carson V, Latimer-Cheung AE, et al. Sedentary Behavior Research Network (SBRN) - Terminology Consensus Project process and outcome. Int J Behav Nutr Phys Act. 2017;14(1):75. 
2. Yang L, Cao C, Kantor ED, Nguyen LH, Zheng X, Park Y, et al. Trends in Sedentary Behavior Among the US Population, 2001-2016. JAMA. 2019;321(16):1587-97.

3. Bull FC, Al-Ansari SS, Biddle S, Borodulin K, Buman MP, Cardon G, et al. World Health Organization 2020 guidelines on physical activity and sedentary behaviour. Br J Sports Med. 2020;54(24):1451-62.

4. Zong G, Zhang Z, Yang Q, Wu H, Hu FB, Sun Q. Total and regional adiposity measured by dual-energy X-ray absorptiometry and mortality in NHANES 1999-2006. Obesity (Silver Spring). 2016;24(11):2414-21.

5. Goodpaster BH, Krishnaswami S, Harris TB, Katsiaras A, Kritchevsky SB, Simonsick EM, et al. Obesity, Regional Body Fat Distribution, and the Metabolic Syndrome in Older Men and Women. Archives of Internal Medicine. 2005;165(7):777-83.

6. Lee DH, Keum N, Hu FB, Orav EJ, Rimm EB, Willett WC, et al. Predicted lean body mass, fat mass, and all cause and cause specific mortality in men: prospective US cohort study. BMJ (Clinical research ed). 2018;362:k2575.

7. Swartz AM, Squires L, Strath SJ. Energy expenditure of interruptions to sedentary behavior. Int J Behav Nutr Phys Act. 2011;8:69.

8. Hill JO, Wyatt HR, Peters JC. Energy balance and obesity. Circulation. 2012;126(1):126-32.

9. Campbell SDI, Brosnan BJ, Chu AKY, Skeaff CM, Rehrer NJ, Perry TL, et al. Sedentary Behavior and Body Weight and Composition in Adults: A Systematic Review and Meta-analysis of Prospective Studies. Sports Med. 2018;48(3):585-95.

10. Henson J, Edwardson CL, Morgan B, Horsfield MA, Bodicoat DH, Biddle SJ, et al. Associations of Sedentary Time with Fat Distribution in a High-Risk Population. Med Sci Sports Exerc. 2015;47(8):1727-34.

11. Mun J, Kim Y, Farnsworth JL, Suh S, Kang M. Association between objectively measured sedentary behavior and a criterion measure of obesity among adults. Am J Hum Biol. 2018;30(2).

12. Wanner M, Richard A, Martin B, Faeh D, Rohrmann S. Associations between self-reported and objectively measured physical activity, sedentary behavior and overweight/obesity in NHANES 2003-2006. Int J Obes (Lond). 2017;41(1):186-93.

13. Cao C, Cade WT, Li S, McMillan J, Friedenreich C, Yang L. Association of Balance Function With All-Cause and Cause-Specific Mortality Among US Adults. JAMA Otolaryngology-Head \& Neck Surgery. 2021;147(5):460-8.

14. Liao J, Cao C, Hur J, Cohen J, Chen W, Zong X, et al. Association of sedentary patterns with body fat distribution among US children and adolescents: a population-based study. International Journal of Obesity. 2021;45(9):2048-57.

15. Abufaraj M, Siyam A, Xu T, Imm K, Cao C, Waldoer T, et al. Association Between Body Fat Mass and Kidney Stones in US Adults: Analysis of the National Health and Nutrition Examination Survey 2011-2018. European Urology Focus. 2021.

16. Bull FC, Maslin TS, Armstrong T. Global Physical Activity Questionnaire (GPAQ): Nine Country Reliability and Validity Study. Journal of Physical Activity and Health. 2009;6(6):790-804.

17. Ekelund U, Steene-Johannessen J, Brown WJ, Fagerland MW, Owen N, Powell KE, et al. Does physical activity attenuate, or even eliminate, the detrimental association of sitting time with mortality? A harmonised metaanalysis of data from more than 1 million men and women. Lancet. 2016;388(10051):1302-10.

18. Stamatakis E, Gale J, Bauman A, Ekelund U, Hamer M, Ding D. Sitting Time, Physical Activity, and Risk of Mortality in Adults. J Am Coll Cardiol. 2019;73(16):2062-72.

19. Ussery EN, Fulton JE, Galuska DA, Katzmarzyk PT, Carlson SA. Joint Prevalence of Sitting Time and Leisure-Time Physical Activity Among US Adults, 2015-2016. JAMA. 2018;320(19):2036-8. 
20. Piercy KL, Troiano RP, Ballard RM, Carlson SA, Fulton JE, Galuska DA, et al. The Physical Activity Guidelines for Americans. JAMA. 2018;320(19):2020-8.

21. Krebs-Smith SM, Pannucci TE, Subar AF, Kirkpatrick SI, Lerman JL, Tooze JA, et al. Update of the Healthy Eating Index: HEl-2015. J Acad Nutr Diet. 2018;118(9):1591-602.

22. Cao C, Hu L, Xu T, Liu Q, Koyanagi A, Yang L, et al. Prevalence, correlates and misperception of depression symptoms in the United States, NHANES 2015-2018. Journal of Affective Disorders. 2020;269:51-7.

23. Ekelund U, Tarp J, Fagerland MW, Johannessen JS, Hansen BH, Jefferis BJ, et al. Joint associations of accelerometer measured physical activity and sedentary time with all-cause mortality: a harmonised meta-analysis in more than 44000 middle-aged and older individuals. Br J Sports Med. 2020;54(24):1499-506.

24. Chomistek AK, Manson JE, Stefanick ML, Lu B, Sands-Lincoln M, Going SB, et al. Relationship of sedentary behavior and physical activity to incident cardiovascular disease: results from the Women's Health Initiative. J Am Coll Cardiol. 2013;61(23):2346-54.

25. Huang BH, Hamer M, Chastin S, Pearson N, Koster A, Stamatakis E. Cross-sectional associations of devicemeasured sedentary behaviour and physical activity with cardio-metabolic health in the 1970 British Cohort Study. Diabet Med. 2021;38(2):e14392.

26. Chastin S, McGregor D, Palarea-Albaladejo J, Diaz KM, Hagstromer M, Hallal PC, et al. Joint association between accelerometry-measured daily combination of time spent in physical activity, sedentary behaviour and sleep and all-cause mortality: a pooled analysis of six prospective cohorts using compositional analysis. Br J Sports Med. 2021;55(22):1277-85.

27. Cao C, Friedenreich CM, Yang L. Association of Daily Sitting Time and Leisure-Time Physical Activity With Survival Among US Cancer Survivors. JAMA Oncol. 2022.

28. Stephens BR, Granados K, Zderic TW, Hamilton MT, Braun B. Effects of 1 day of inactivity on insulin action in healthy men and women: interaction with energy intake. Metabolism. 2011;60(7):941-9.

29. Lerma NL, Keenan KG, Strath SJ, Forseth BM, Cho CC, Swartz AM. Muscle activation and energy expenditure of sedentary behavior alternatives in young and old adults. Physiol Meas. 2016;37(10):1686-700.

30. Jensen MD. Role of body fat distribution and the metabolic complications of obesity. J Clin Endocrinol Metab. 2008;93(11 Suppl 1):S57-63.

31. Ebbert JO, Jensen MD. Fat depots, free fatty acids, and dyslipidemia. Nutrients. 2013;5(2):498-508.

32. Westerterp KR, Yamada Y, Sagayama H, Ainslie PN, Andersen LF, Anderson LJ, et al. Physical activity and fat-free mass during growth and in later life. Am J Clin Nutr. 2021.

33. Hamilton MT, Hamilton DG, Zderic TW. Role of low energy expenditure and sitting in obesity, metabolic syndrome, type 2 diabetes, and cardiovascular disease. Diabetes. 2007;56(11):2655-67.

34. Patterson R, McNamara E, Tainio M, de Sa TH, Smith AD, Sharp SJ, et al. Sedentary behaviour and risk of allcause, cardiovascular and cancer mortality, and incident type 2 diabetes: a systematic review and dose response meta-analysis. Eur J Epidemiol. 2018;33(9):811-29.

35. Stamatakis E, Ekelund U, Ding D, Hamer M, Bauman AE, Lee IM. Is the time right for quantitative public health guidelines on sitting? A narrative review of sedentary behaviour research paradigms and findings. Br J Sports Med. 2019;53(6):377-82.

\section{Tables}


Table 1. Characteristics of the US Adults $\geq 20$ years According to Sex, NHANES 2011-2018

No. of Participants (Weighted \%)

\begin{tabular}{|c|c|c|c|}
\hline & All & Male & Female \\
\hline Overall & 10808 (100) & $5437(100)$ & $5371(100)$ \\
\hline \multicolumn{4}{|l|}{ Race/ethnicity } \\
\hline Non-Hispanic white & 3741 (61.3) & $1889(62.1)$ & $1852(60.5)$ \\
\hline Non-Hispanic black & 2261 (11.2) & 1136 (11.3) & $1125(11.0)$ \\
\hline Hispanic & $2746(17.9)$ & $1436(17.1)$ & $1310(18.7)$ \\
\hline Other & $2060(9.6)$ & $976(9.5)$ & $1084(9.8)$ \\
\hline \multicolumn{4}{|l|}{ Family poverty ratio } \\
\hline$<1.3$ & $3222(21.9)$ & $1689(23.0)$ & $1533(20.8)$ \\
\hline $1.3-<3.5$ & 4441 (38.8) & 2179 (37.7) & $2262(39.8)$ \\
\hline$\geq 3.5$ & 3145 (39.3) & 1569 (39.3) & $1576(39.4)$ \\
\hline \multicolumn{4}{|l|}{ Education } \\
\hline$<$ High school & 1976 (13.0) & $897(11.6)$ & $1079(14.4)$ \\
\hline High school & $2360(21.7)$ & $1064(18.7)$ & $1296(24.6)$ \\
\hline >High school & $6472(65.4)$ & $3476(69.7)$ & $2996(61.1)$ \\
\hline \multicolumn{4}{|l|}{ Smoking Status } \\
\hline Never & $6590(59.1)$ & $3725(64.7)$ & $2865(53.6)$ \\
\hline Past & 1793 (19.3) & $713(16.0)$ & $1080(22.6)$ \\
\hline Current & $2425(21.6)$ & 999 (19.3) & $1426(23.8)$ \\
\hline \multicolumn{4}{|l|}{ Diabetes } \\
\hline No & $10008(94.2)$ & $5037(94.4)$ & $4971(94.0)$ \\
\hline Yes & $807(5.8)$ & $406(5.6)$ & $401(6.0)$ \\
\hline \multicolumn{4}{|c|}{ Cardiovascular Disease } \\
\hline No & $10388(96.8)$ & $5230(96.9)$ & $5158(96.7)$ \\
\hline Yes & $420(3.2)$ & $207(3.1)$ & $213(3.3)$ \\
\hline \multicolumn{4}{|l|}{ Cancer } \\
\hline No & $10473(96.4)$ & $5192(94.9)$ & $5281(97.9)$ \\
\hline Yes & $335(3.6)$ & $245(5.1)$ & $90(2.1)$ \\
\hline \multicolumn{4}{|c|}{ Daily Sitting Time, h/d } \\
\hline$<4$ & $2690(22.2)$ & $1333(21.6)$ & $1357(22.9)$ \\
\hline
\end{tabular}




\begin{tabular}{llll}
$4-<6$ & $2524(23.2)$ & $1252(23.4)$ & $1272(23.0)$ \\
\hline $6-8$ & $3149(28.9)$ & $1588(28.8)$ & $1561(29.0)$ \\
\hline$>8$ & $2445(25.7)$ & $1264(26.2)$ & $1181(25.2)$ \\
\hline LTPA & & & \\
\hline Inactive & $4835(40.6)$ & $2547(41.5)$ & $2288(39.8)$ \\
\hline Insufficient Active & $1641(16.1)$ & $931(17.6)$ & $710(14.5)$ \\
\hline Physically Active & $4332(43.3)$ & $1959(40.9)$ & $2373(45.7)$
\end{tabular}

a Sample size was weighted to be nationally representative. 
Table 2. Association of Daily Sitting Time and Leisure-Time Physical Activity with Total and Trunk fat Percentage Among US Adults $\geq 20$ years, NHANES 2011-2018

$\beta$-coefficient $(95 \% \mathrm{Cl})$

Total Fat Percentage

$\begin{array}{ll}\text { MV model } 1^{\mathrm{a}} & \mathrm{MV} \text { model } \\ 2^{\mathrm{a}, \mathrm{b}}\end{array}$
MV model

$3^{a, b, c}$
Trunk Fat Percentage

MV model $1^{a} \quad M V$ model

$2^{a, b}$
MV model

$3^{a, b, c}$

\section{Male}

Daily Sitting

Time, $\mathrm{h} / \mathrm{d}$

\begin{tabular}{|c|c|c|c|c|c|c|}
\hline$<4$ & 1 [reference] & 1 [reference] & 1 [reference] & 1 [reference] & 1 [reference] & 1 [reference] \\
\hline $4-<6$ & $\begin{array}{l}0.54(-0.06 \\
\text { to } 1.14)\end{array}$ & $\begin{array}{l}0.68 \text { ( } 0.08 \text { to } \\
1.29)\end{array}$ & $\begin{array}{l}0.53(-0.11 \\
\text { to } 1.18)\end{array}$ & $\begin{array}{l}0.70 \text { (0.03 to } \\
1.37)\end{array}$ & $\begin{array}{l}0.87 \text { ( } 0.19 \text { to } \\
1.55)\end{array}$ & $\begin{array}{l}0.66(-0.05 \text { to } \\
1.38)\end{array}$ \\
\hline $6-8$ & $\begin{array}{l}1.49 \text { (0.88 to } \\
2.11)\end{array}$ & $\begin{array}{l}1.42 \text { ( } 0.78 \text { to } \\
2.07)\end{array}$ & $\begin{array}{l}1.30 \text { (0.64 to } \\
1.97)\end{array}$ & $\begin{array}{l}1.65 \text { ( } 0.97 \text { to } \\
2.33)\end{array}$ & $\begin{array}{l}1.57(0.86 \text { to } \\
2.28)\end{array}$ & $\begin{array}{l}1.44(0.70 \text { to } \\
2.19)\end{array}$ \\
\hline$>8$ & $\begin{array}{l}1.90 \text { (1.17 to } \\
2.62)\end{array}$ & $\begin{array}{l}1.87 \text { (1.11 to } \\
2.63)\end{array}$ & $\begin{array}{l}1.84 \text { (1.06 to } \\
2.62)\end{array}$ & $\begin{array}{l}2.05 \text { ( } 1.22 \text { to } \\
2.89)\end{array}$ & $\begin{array}{l}2.07 \text { ( } 1.20 \text { to } \\
2.93)\end{array}$ & $\begin{array}{l}2.03 \text { (1.16 to } \\
2.90)\end{array}$ \\
\hline $\begin{array}{l}\text { per } 1 \mathrm{~h} / \mathrm{d} \\
\text { increase }\end{array}$ & $\begin{array}{l}0.21 \text { ( } 0.14 \text { to } \\
0.28)\end{array}$ & $\begin{array}{l}0.20(0.13 \text { to } \\
0.27)\end{array}$ & $\begin{array}{l}0.20(0.13 \text { to } \\
0.27)\end{array}$ & $\begin{array}{l}0.22(0.14 \text { to } \\
0.30)\end{array}$ & $\begin{array}{l}0.21 \text { ( } 0.13 \text { to } \\
0.30)\end{array}$ & $\begin{array}{l}0.22 \text { (0.14 to } \\
0.30)\end{array}$ \\
\hline
\end{tabular}

LTPA

\begin{tabular}{|c|c|c|c|c|c|c|}
\hline Inactive & 1 [reference] & 1 [reference] & 1 [reference] & 1 [reference] & 1 [reference] & 1 [reference] \\
\hline $\begin{array}{l}\text { Insufficiently } \\
\text { Active }\end{array}$ & $\begin{array}{l}-0.65(-1.43 \\
\text { to } 0.13)\end{array}$ & $\begin{array}{l}-0.56(-1.31 \\
\text { to } 0.19)\end{array}$ & $\begin{array}{l}-0.51(-1.24 \\
\text { to } 0.21)\end{array}$ & $\begin{array}{l}-0.73(-1.63 \\
\text { to } 0.16)\end{array}$ & $\begin{array}{l}-0.64(-1.48 \\
\text { to } 0.20)\end{array}$ & $\begin{array}{l}-0.66(-1.47 \\
\text { to } 0.15)\end{array}$ \\
\hline $\begin{array}{l}\text { Physically } \\
\text { Active }\end{array}$ & $\begin{array}{l}-2.41(-2.96 \\
\text { to }-1.86)\end{array}$ & $\begin{array}{l}-2.13(-2.68 \\
\text { to }-1.59)\end{array}$ & $\begin{array}{l}-1.98(-2.52 \\
\text { to }-1.45)\end{array}$ & $\begin{array}{l}-2.55(-3.15 \\
\text { to }-1.95)\end{array}$ & $\begin{array}{l}-2.26(-2.87 \\
\text { to }-1.64)\end{array}$ & $\begin{array}{l}-2.12(-2.71 \\
\text { to }-1.52)\end{array}$ \\
\hline
\end{tabular}

Female

Daily Sitting

Time, h/d

\begin{tabular}{|c|c|c|c|c|c|c|}
\hline$<4$ & 1 [reference] & 1 [reference] & 1 [reference] & 1 [reference] & 1 [reference] & 1 [reference] \\
\hline $4-<6$ & $\begin{array}{l}0.56(0.01 \text { to } \\
1.12)\end{array}$ & $\begin{array}{l}0.62(0.08 \text { to } \\
1.16)\end{array}$ & $\begin{array}{l}0.53(-0.04 \\
\text { to } 1.10)\end{array}$ & $\begin{array}{l}0.63(-0.06 \text { to } \\
1.33)\end{array}$ & $\begin{array}{l}0.70(0.03 \text { to } \\
1.37)\end{array}$ & $\begin{array}{l}0.65(-0.07 \text { to } \\
1.38)\end{array}$ \\
\hline $6-8$ & $\begin{array}{l}1.45(0.89 \text { to } \\
2.00)\end{array}$ & $\begin{array}{l}1.39(0.85 \text { to } \\
1.94)\end{array}$ & $\begin{array}{l}1.24(0.73 \text { to } \\
1.75)\end{array}$ & $\begin{array}{l}1.62(0.90 \text { to } \\
2.34)\end{array}$ & $\begin{array}{l}1.55(0.87 \text { to } \\
2.24)\end{array}$ & $\begin{array}{l}1.32 \text { ( } 0.67 \text { to } \\
1.98)\end{array}$ \\
\hline$>8$ & $\begin{array}{l}2.22 \text { (1.64 to } \\
2.80)\end{array}$ & $\begin{array}{l}2.17 \text { ( } 1.61 \text { to } \\
2.73 \text { ) }\end{array}$ & $\begin{array}{l}1.97 \text { ( } 1.39 \text { to } \\
2.55)\end{array}$ & $\begin{array}{l}2.29 \text { (1.47 to } \\
3.12)\end{array}$ & $\begin{array}{l}2.19 \text { (1.40 to } \\
2.98)\end{array}$ & $\begin{array}{l}1.91 \text { ( } 1.11 \text { to } \\
2.70)\end{array}$ \\
\hline $\begin{array}{l}\text { per } 1 \mathrm{~h} / \mathrm{d} \\
\text { increase }\end{array}$ & $\begin{array}{l}0.26(0.19 \text { to } \\
0.32)\end{array}$ & $\begin{array}{l}0.25 \text { (0.18 to } \\
0.31)\end{array}$ & $\begin{array}{l}0.23(0.17 \text { to } \\
0.29)\end{array}$ & $\begin{array}{l}0.27 \text { (0.18 to } \\
0.36)\end{array}$ & $\begin{array}{l}0.26(0.17 \text { to } \\
0.34)\end{array}$ & $\begin{array}{l}0.23(0.14 \text { to } \\
0.31)\end{array}$ \\
\hline
\end{tabular}

LTPA

Inactive

Insufficiently

Active
1 [reference]

$-0.63(-1.10$

to -0.15$)$
1 [reference] 1 [reference]

$-0.55(-1.05$

to -0.05$)$
$-0.47(-0.97$

to 0.03$)$
1 [reference]

$-0.67(-1.31$

to -0.04$)$
1 [reference] 1 [reference]

$-0.57(-1.22 \quad-0.55(-1.22$ to 0.08$)$ to 0.13$)$ 
a Multivariable (MV) model additionally adjusted for age (year), sex (male or female), race (non-Hispanic white, non-Hispanic black, Hispanic, and other), education attainment (less than high school, high school graduate, above high school), family poverty ratio $(<1.30,1.30-3.49$, or $\geq 3.5)$

${ }^{\mathrm{b}}$ Additionally adjusted for smoking status (never, former, and current), alcohol use (never, former, and current), Total Energy Intake and Healthy Eating Index-2015

${ }^{\mathrm{c}}$ Additionally adjusted for hypertension (yes or no), hypercholesterolemia (yes or no), history of diabetes (yes or no), history of CVD (yes or no), history of cancer (yes or no), and depression 
Table 3. Association of Daily Sitting Time with Total and Trunk fat Percentage Among US Adults $\geq 20$ years Stratified by Leisure-Time Physical Activity, NHANES 2011-2018

LTPA

$\begin{array}{ll}\text { Daily } & \beta \text {-coefficient }(95 \% \mathrm{Cl}) \\ \text { Sitting } & \\ \text { Time, } \\ \text { h/d }\end{array}$

$\begin{array}{ll}\text { MV model } & M V \text { model } \\ 1^{\mathrm{a}} & 2^{\mathrm{a}, \mathrm{b}}\end{array}$

Trunk Fat Percentage

MV model
$3^{\mathrm{a}, \mathrm{b}, \mathrm{c}}$

\section{MV model $\quad$ MV model $1^{\mathrm{a}}$}

MV model $3^{\mathrm{a}, \mathrm{b}, \mathrm{c}}$

\section{Male}

Physically Active

\begin{tabular}{|c|c|c|c|c|c|c|}
\hline$<4$ & $\begin{array}{l}1 \\
\text { [reference] }\end{array}$ & $\begin{array}{l}1 \\
\text { [reference] }\end{array}$ & $\begin{array}{l}1 \\
\text { [reference] }\end{array}$ & $\begin{array}{l}1 \\
\text { [reference] }\end{array}$ & $\begin{array}{l}1 \\
\text { [reference] }\end{array}$ & $\begin{array}{l}1 \\
\text { [reference] }\end{array}$ \\
\hline $4<6$ & $\begin{array}{l}0.69 \\
(-0.37 \text { to } \\
1.75)\end{array}$ & $\begin{array}{l}0.70 \\
(-0.34 \text { to } \\
1.75)\end{array}$ & $\begin{array}{l}0.56 \\
(-0.52 \text { to } \\
1.64)\end{array}$ & $\begin{array}{l}0.86(-0.3 \\
\text { to } 2.02)\end{array}$ & $\begin{array}{l}0.85 \\
(-0.31 \text { to } \\
2.01)\end{array}$ & $\begin{array}{l}0.72 \\
(-0.43 \text { to } \\
1.87)\end{array}$ \\
\hline $6-8$ & $\begin{array}{l}1.24(0.40 \\
\text { to } 2.07)\end{array}$ & $\begin{array}{l}1.14(0.30 \\
\text { to } 1.98)\end{array}$ & $\begin{array}{l}1.15(0.25 \\
\text { to } 2.06)\end{array}$ & $\begin{array}{l}1.13(0.21 \\
\text { to } 2.04)\end{array}$ & $\begin{array}{l}1.05(0.14 \\
\text { to } 1.97)\end{array}$ & $\begin{array}{l}1.30(0.31 \\
\text { to } 2.30)\end{array}$ \\
\hline$>8$ & $\begin{array}{l}1.68(0.86 \\
\text { to } 2.50)\end{array}$ & $\begin{array}{l}1.70(0.87 \\
\text { to } 2.54)\end{array}$ & $\begin{array}{l}1.47(0.55 \\
\text { to } 2.38)\end{array}$ & $\begin{array}{l}1.60(0.68 \\
\text { to } 2.51)\end{array}$ & $\begin{array}{l}1.71(0.78 \\
\text { to } 2.64)\end{array}$ & $\begin{array}{l}1.71(0.73 \\
\text { to } 2.70)\end{array}$ \\
\hline
\end{tabular}

Inactive/Insufficiently <4 Active

\begin{tabular}{|c|c|c|c|c|c|c|}
\hline$<4$ & $\begin{array}{l}1 \\
\text { [reference] }\end{array}$ & $\begin{array}{l}1 \\
\text { [reference] }\end{array}$ & $\begin{array}{l}1 \\
\text { [reference] }\end{array}$ & $\begin{array}{l}1 \\
\text { [reference] }\end{array}$ & $\begin{array}{l}1 \\
\text { [reference] }\end{array}$ & $\begin{array}{l}1 \\
\text { [reference] }\end{array}$ \\
\hline $4-<6$ & $\begin{array}{l}0.22 \\
(-0.54 \text { to } \\
0.98)\end{array}$ & $\begin{array}{l}0.48 \\
(-0.27 \text { to } \\
1.23)\end{array}$ & $\begin{array}{l}0.35 \\
(-0.47 \text { to } \\
1.17)\end{array}$ & $\begin{array}{l}0.27 \\
(-0.62 \text { to } \\
1.16)\end{array}$ & $\begin{array}{l}0.58 \\
(-0.30 \text { to } \\
1.46)\end{array}$ & $\begin{array}{l}0.44 \\
(-0.52 \text { to } \\
1.39)\end{array}$ \\
\hline 6-8 & $\begin{array}{l}1.79(0.98 \\
\text { to } 2.59)\end{array}$ & $\begin{array}{l}1.70(0.88 \\
\text { to } 2.51)\end{array}$ & $\begin{array}{l}1.46(0.61 \\
\text { to } 2.31)\end{array}$ & $\begin{array}{l}1.80(0.96 \\
\text { to } 2.64)\end{array}$ & $\begin{array}{l}1.68(0.82 \\
\text { to } 2.53)\end{array}$ & $\begin{array}{l}1.56(0.66 \\
\text { to } 2.47)\end{array}$ \\
\hline$>8$ & $\begin{array}{l}2.31(1.28 \\
\text { to } 3.35)\end{array}$ & $\begin{array}{l}2.22(1.17 \\
\text { to } 3.28)\end{array}$ & $\begin{array}{l}2.13(1.04 \\
\text { to } 3.23)\end{array}$ & $\begin{array}{l}2.14(0.97 \\
\text { to } 3.32)\end{array}$ & $\begin{array}{l}2.10(0.92 \\
\text { to } 3.28)\end{array}$ & $\begin{array}{l}2.24(1.04 \\
\text { to } 3.43)\end{array}$ \\
\hline
\end{tabular}

\section{Female}

Physically Active

\begin{tabular}{|c|c|c|c|c|c|c|c|}
\hline \multirow[t]{4}{*}{ Physically Active } & $<4$ & $\begin{array}{l}1 \\
\text { [reference] }\end{array}$ & $\begin{array}{l}1 \\
\text { [reference] }\end{array}$ & $\begin{array}{l}1 \\
\text { [reference] }\end{array}$ & $\begin{array}{l}1 \\
\text { [reference] }\end{array}$ & $\begin{array}{l}1 \\
\text { [reference] }\end{array}$ & $\begin{array}{l}1 \\
\text { [reference] }\end{array}$ \\
\hline & $4-66$ & $\begin{array}{l}0.32 \\
(-0.64 \text { to } \\
1.28)\end{array}$ & $\begin{array}{l}0.33 \\
(-0.61 \text { to } \\
1.27)\end{array}$ & $\begin{array}{l}0.34 \\
(-0.63 \text { to } \\
1.31)\end{array}$ & $\begin{array}{l}0.36 \\
(-0.80 \text { to } \\
1.51)\end{array}$ & $\begin{array}{l}0.39 \\
(-0.77 \text { to } \\
1.54)\end{array}$ & $\begin{array}{l}0.64 \\
(-0.54 \text { to } \\
1.82)\end{array}$ \\
\hline & $6-8$ & $\begin{array}{l}1.18(0.39 \\
\text { to } 1.98)\end{array}$ & $\begin{array}{l}1.11(0.31 \\
\text { to } 1.91)\end{array}$ & $\begin{array}{l}1.36(0.54 \\
\text { to } 2.17)\end{array}$ & $\begin{array}{l}1.30(0.32 \\
\text { to } 2.28)\end{array}$ & $\begin{array}{l}1.22(0.25 \\
\text { to } 2.18)\end{array}$ & $\begin{array}{l}1.65(0.65 \\
\text { to } 2.65)\end{array}$ \\
\hline & $>8$ & $\begin{array}{l}1.76(0.79 \\
\text { to } 2.73)\end{array}$ & $\begin{array}{l}1.62(0.66 \\
\text { to } 2.57)\end{array}$ & $\begin{array}{l}1.75(0.75 \\
\text { to } 2.75)\end{array}$ & $\begin{array}{l}1.64(0.45 \\
\text { to } 2.84)\end{array}$ & $\begin{array}{l}1.42(0.24 \\
\text { to } 2.60)\end{array}$ & $\begin{array}{l}1.65(0.44 \\
\text { to } 2.87)\end{array}$ \\
\hline \multirow[t]{5}{*}{$\begin{array}{l}\text { Inactive/Insufficiently } \\
\text { Active }\end{array}$} & $<4$ & $\begin{array}{l}1 \\
\text { [reference] }\end{array}$ & $\begin{array}{l}1 \\
\text { [reference] }\end{array}$ & $\begin{array}{l}1 \\
\text { [reference] }\end{array}$ & $\begin{array}{l}1 \\
\text { [reference] }\end{array}$ & $\begin{array}{l}1 \\
\text { [reference] }\end{array}$ & $\begin{array}{l}1 \\
\text { [reference] }\end{array}$ \\
\hline & $4<6$ & $\begin{array}{l}0.77(0.09 \\
\text { to } 1.45)\end{array}$ & $\begin{array}{l}0.91(0.24 \\
\text { to } 1.58)\end{array}$ & $\begin{array}{l}0.75(0.07 \\
\text { to } 1.42)\end{array}$ & $\begin{array}{l}0.89(0.02 \\
\text { to } 1.76)\end{array}$ & $\begin{array}{l}1.03(0.21 \\
\text { to } 1.84)\end{array}$ & $\begin{array}{l}0.78 \\
(-0.02 \text { to } \\
1.58)\end{array}$ \\
\hline & $6-8$ & $\begin{array}{l}0.86(0.14 \\
\text { to } 1.58)\end{array}$ & $\begin{array}{l}0.79(0.10 \\
\text { to } 1.47)\end{array}$ & $\begin{array}{l}0.89(0.20 \\
\text { to } 1.59)\end{array}$ & $\begin{array}{l}0.91 \\
(-0.06 \text { to } \\
1.88)\end{array}$ & $\begin{array}{l}0.79 \\
(-0.10 \text { to } \\
1.69)\end{array}$ & $\begin{array}{l}0.79 \\
(-0.08 \text { to } \\
1.65)\end{array}$ \\
\hline & $>8$ & $1.86(1.15$ & $1.87(1.18$ & $1.91(1.25$ & $2.03(0.98$ & $2.03(0.99$ & $1.86(0.92$ \\
\hline & \multicolumn{7}{|c|}{ Page $14 / 17$} \\
\hline
\end{tabular}

Inactive/Insufficiently $\quad<4$ Active 
${ }^{\text {a }}$ Multivariable (MV) model additionally adjusted for age (year), sex (male or female), non-Hispanic white, nonHispanic black, Hispanic, and other), education attainment (less than high school, high school graduate, above high school), family poverty ratio $(<1.30,1.30-3.49$, or $\geq 3.5)$

${ }^{\mathrm{b}}$ Additionally adjusted for smoking status (never, former, and current), alcohol use (never, former, and current), Total Energy Intake and Healthy Eating Index-2015

${ }^{c}$ Additionally adjusted for hypertension (yes or no), hypercholesterolemia (yes or no), history of diabetes (yes or no), history of CVD (yes or no), history of cancer (yes or no), and depression 
Table 4. Joint Association of Daily Sitting Time and Leisure-Time Physical Activity with Total and Trunk fat Percentage Among US Adults $\geq 20$ years, NHANES 2011-2018

LTPA

\section{Daily $\quad \beta$-coefficient $(95 \% \mathrm{Cl})$ \\ Sitting \\ Time, Total Fat Percentage \\ $\mathrm{h} / \mathrm{d}$}

$\begin{array}{ll}\text { MV model } & \text { MV model } \\ 1^{\mathrm{a}} & 2^{\mathrm{a}, \mathrm{b}}\end{array}$

Trunk Fat Percentage

MV model
$3^{\mathrm{a}, \mathrm{b}, \mathrm{c}}$

$\begin{array}{ll}\text { MV model } & \text { MV model } \\ 1^{\mathrm{a}} & 2^{\mathrm{a}, \mathrm{b}}\end{array}$

MV model

$3^{\mathrm{a}, \mathrm{b}, \mathrm{c}}$

\section{Male}

\begin{tabular}{|c|c|c|c|c|c|c|c|}
\hline \multirow[t]{4}{*}{ Physically Active } & $<4$ & $\begin{array}{l}1 \\
\text { [reference] }\end{array}$ & $\begin{array}{l}1 \\
\text { [reference] }\end{array}$ & $\begin{array}{l}1 \\
\text { [reference] }\end{array}$ & $\begin{array}{l}1 \\
\text { [reference] }\end{array}$ & $\begin{array}{l}1 \\
\text { [reference] }\end{array}$ & $\begin{array}{l}1 \\
\text { [reference] }\end{array}$ \\
\hline & $4-<6$ & $\begin{array}{l}0.73 \\
(-0.35 \text { to } \\
1.81)\end{array}$ & $\begin{array}{l}0.69 \\
(-0.39 \text { to } \\
1.78)\end{array}$ & $\begin{array}{l}0.54 \\
(-0.55 \text { to } \\
1.64)\end{array}$ & $\begin{array}{l}0.95 \\
(-0.25 \text { to } \\
2.15)\end{array}$ & $\begin{array}{l}0.91 \\
(-0.30 \text { to } \\
2.12)\end{array}$ & $\begin{array}{l}0.7(-0.49 \\
\text { to } 1.90)\end{array}$ \\
\hline & $6-8$ & $\begin{array}{l}1.03(0.20 \\
\text { to } 1.85)\end{array}$ & $\begin{array}{l}0.96(0.10 \\
\text { to } 1.83)\end{array}$ & $\begin{array}{l}1.01(0.14 \\
\text { to } 1.88)\end{array}$ & $\begin{array}{l}1.21(0.24 \\
\text { to } 2.19)\end{array}$ & $\begin{array}{l}1.14(0.15 \\
\text { to } 2.13)\end{array}$ & $\begin{array}{l}1.17(0.17 \\
\text { to } 2.16)\end{array}$ \\
\hline & $>8$ & $\begin{array}{l}1.15(0.24 \\
\text { to } 2.06)\end{array}$ & $\begin{array}{l}1.21(0.26 \\
\text { to } 2.15)\end{array}$ & $\begin{array}{l}1.15(0.22 \\
\text { to } 2.07)\end{array}$ & $\begin{array}{l}1.43(0.39 \\
\text { to } 2.48)\end{array}$ & $\begin{array}{l}1.51(0.46 \\
\text { to } 2.57)\end{array}$ & $\begin{array}{l}1.40(0.38 \\
\text { to } 2.42)\end{array}$ \\
\hline \multirow[t]{4}{*}{$\begin{array}{l}\text { Inactive/Insufficiently } \\
\text { Active }\end{array}$} & $<4$ & $\begin{array}{l}1.70(0.82 \\
\text { to } 2.57)\end{array}$ & $\begin{array}{l}1.41(0.57 \\
\text { to } 2.26)\end{array}$ & $\begin{array}{l}1.34(0.50 \\
\text { to } 2.19)\end{array}$ & $\begin{array}{l}1.91(0.88 \\
\text { to } 2.95)\end{array}$ & $\begin{array}{l}1.59(0.61 \\
\text { to } 2.57)\end{array}$ & $\begin{array}{l}1.48(0.51 \\
\text { to } 2.45)\end{array}$ \\
\hline & $4-<6$ & $\begin{array}{l}2.08(1.28 \\
\text { to } 2.88)\end{array}$ & $\begin{array}{l}2.08(1.28 \\
\text { to } 2.87)\end{array}$ & $\begin{array}{l}1.85(1.05 \\
\text { to } 2.66)\end{array}$ & $\begin{array}{l}2.40(1.46 \\
\text { to } 3.33)\end{array}$ & $\begin{array}{l}2.42(1.48 \\
\text { to } 3.36)\end{array}$ & $\begin{array}{l}2.09(1.17 \\
\text { to } 3.02)\end{array}$ \\
\hline & $6-8$ & $\begin{array}{l}3.59(2.68 \\
\text { to } 4.50)\end{array}$ & $\begin{array}{l}3.23(2.32 \\
\text { to } 4.14)\end{array}$ & $\begin{array}{l}2.91(2.03 \\
\text { to } 3.80)\end{array}$ & $\begin{array}{l}3.94(2.93 \\
\text { to } 4.95)\end{array}$ & $\begin{array}{l}3.53(2.53 \\
\text { to } 4.54)\end{array}$ & $\begin{array}{l}3.17(2.17 \\
\text { to } 4.17)\end{array}$ \\
\hline & $>8$ & $\begin{array}{l}4.22(3.21 \\
\text { to } 5.24)\end{array}$ & $\begin{array}{l}3.86(2.86 \\
\text { to } 4.85)\end{array}$ & $\begin{array}{l}3.79(2.75 \\
\text { to } 4.82)\end{array}$ & $\begin{array}{l}4.50(3.38 \\
\text { to } 5.61)\end{array}$ & $\begin{array}{l}4.13(3.05 \\
\text { to } 5.22)\end{array}$ & $\begin{array}{l}4.07(2.95 \\
\text { to } 5.19)\end{array}$ \\
\hline
\end{tabular}

Female

\begin{tabular}{|c|c|c|c|c|c|c|c|}
\hline \multirow[t]{4}{*}{ Physically Active } & $<4$ & $\begin{array}{l}1 \\
\text { [reference] }\end{array}$ & $\begin{array}{l}1 \\
\text { [reference] }\end{array}$ & $\begin{array}{l}1 \\
\text { [reference] }\end{array}$ & $\begin{array}{l}1 \\
\text { [reference] }\end{array}$ & $\begin{array}{l}1 \\
\text { [reference] }\end{array}$ & $\begin{array}{l}1 \\
\text { [reference] }\end{array}$ \\
\hline & $4<6$ & $\begin{array}{l}0.18 \\
(-0.88 \text { to } \\
1.23)\end{array}$ & $\begin{array}{l}0.14 \\
(-0.89 \text { to } \\
1.18)\end{array}$ & $\begin{array}{l}0.15 \\
(-0.89 \text { to } \\
1.20)\end{array}$ & $\begin{array}{l}0.19 \\
(-1.09 \text { to } \\
1.48)\end{array}$ & $\begin{array}{l}0.18 \\
(-1.10 \text { to } \\
1.45)\end{array}$ & $\begin{array}{l}0.40 \\
(-0.86 \text { to } \\
1.66)\end{array}$ \\
\hline & $6-8$ & $\begin{array}{l}1.60(0.68 \\
\text { to } 2.52)\end{array}$ & $\begin{array}{l}1.59(0.7 \\
\text { to } 2.49)\end{array}$ & $\begin{array}{l}1.50(0.63 \\
\text { to } 2.38)\end{array}$ & $\begin{array}{l}1.89(0.75 \\
\text { to } 3.04)\end{array}$ & $\begin{array}{l}1.88(0.80 \\
\text { to } 2.96)\end{array}$ & $\begin{array}{l}1.87(0.83 \\
\text { to } 2.90)\end{array}$ \\
\hline & $>8$ & $\begin{array}{l}2.09(1.08 \\
\text { to } 3.10)\end{array}$ & $\begin{array}{l}1.95(0.99 \\
\text { to } 2.90)\end{array}$ & $\begin{array}{l}1.73(0.74 \\
\text { to } 2.71)\end{array}$ & $\begin{array}{l}2.06(0.80 \\
\text { to } 3.32)\end{array}$ & $\begin{array}{l}1.84(0.63 \\
\text { to } 3.06)\end{array}$ & $\begin{array}{l}1.65(0.45 \\
\text { to } 2.85)\end{array}$ \\
\hline \multirow[t]{4}{*}{$\begin{array}{l}\text { Inactive/Insufficiently } \\
\text { Active }\end{array}$} & $<4$ & $\begin{array}{l}2.41(1.45 \\
\text { to } 3.38)\end{array}$ & $\begin{array}{l}1.95(0.98 \\
\text { to } 2.92)\end{array}$ & $\begin{array}{l}1.84(0.86 \\
\text { to } 2.82)\end{array}$ & $\begin{array}{l}2.68(1.40 \\
\text { to } 3.95)\end{array}$ & $\begin{array}{l}2.09(0.84 \\
\text { to } 3.35)\end{array}$ & $\begin{array}{l}2.12(0.91 \\
\text { to } 3.33)\end{array}$ \\
\hline & $4<6$ & $\begin{array}{l}3.25(2.33 \\
\text { to } 4.18)\end{array}$ & $\begin{array}{l}2.91(2.03 \\
\text { to } 3.79)\end{array}$ & $\begin{array}{l}2.64(1.73 \\
\text { to } 3.56)\end{array}$ & $\begin{array}{l}3.61(2.46 \\
\text { to } 4.77)\end{array}$ & $\begin{array}{l}3.16(2.03 \\
\text { to } 4.28)\end{array}$ & $\begin{array}{l}2.94(1.81 \\
\text { to } 4.07)\end{array}$ \\
\hline & $6-8$ & $\begin{array}{l}3.77(2.82 \\
\text { to } 4.71)\end{array}$ & $\begin{array}{l}3.22(2.29 \\
\text { to } 4.15)\end{array}$ & $\begin{array}{l}2.90(1.99 \\
\text { to } 3.82)\end{array}$ & $\begin{array}{l}4.13(3.01 \\
\text { to } 5.24)\end{array}$ & $\begin{array}{l}3.43(2.33 \\
\text { to } 4.52)\end{array}$ & $\begin{array}{l}3.06(1.98 \\
\text { to } 4.14)\end{array}$ \\
\hline & $>8$ & $\begin{array}{l}4.74(3.84 \\
\text { to } 5.64)\end{array}$ & $\begin{array}{l}4.29(3.39 \\
\text { to } 5.19)\end{array}$ & $\begin{array}{l}3.99(3.09 \\
\text { to } 4.88)\end{array}$ & $\begin{array}{l}5.15(4.03 \\
\text { to } 6.27)\end{array}$ & $\begin{array}{l}4.53(3.41 \\
\text { to } 5.66)\end{array}$ & $\begin{array}{l}4.21(3.09 \\
\text { to } 5.32)\end{array}$ \\
\hline
\end{tabular}

${ }^{a}$ Multivariable (MV) model additionally adjusted for age (year), sex (male or female), non-Hispanic white, non- 
Hispanic black, Hispanic, and other), education attainment (less than high school, high school graduate, above high school), family poverty ratio $(<1.30,1.30-3.49$, or $\geq 3.5)$

${ }^{\mathrm{b}}$ Additionally adjusted for smoking status (never, former, and current), alcohol use (never, former, and current), Total Energy Intake and Healthy Eating Index-2015

${ }^{c}$ Additionally adjusted for hypertension (yes or no), hypercholesterolemia (yes or no), history of diabetes (yes or no), history of CVD (yes or no), history of cancer (yes or no), and depression

\section{Figures}

\section{A. Male}

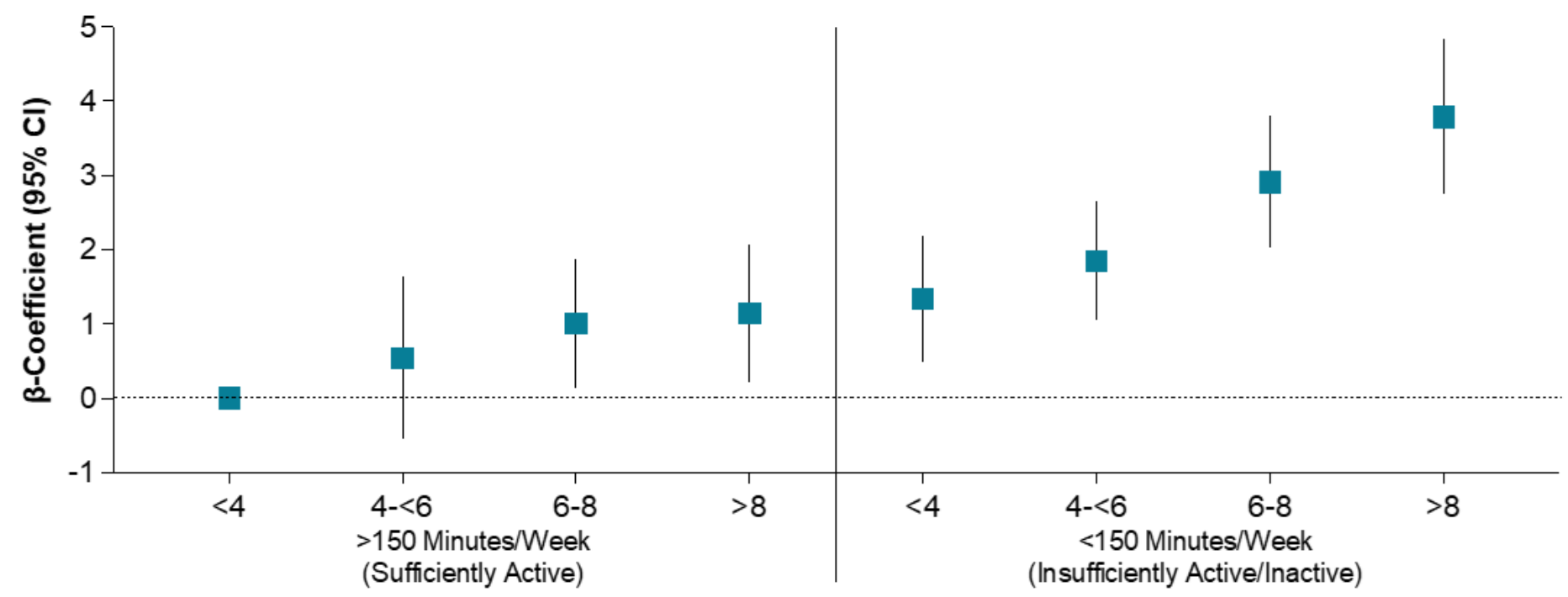

Joint Categories of Total Sitting Time and Leisure-Time Physical Activity

\section{B. Female}

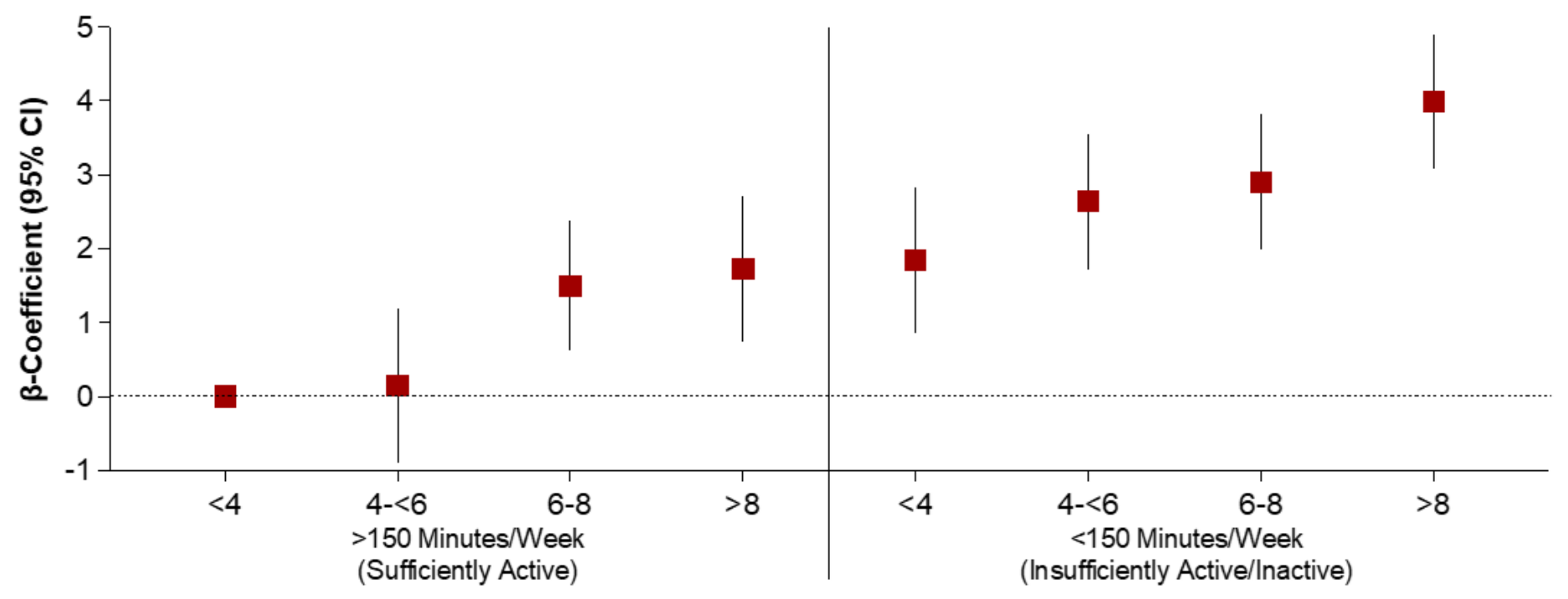

Joint Categories of Total Sitting Time and Leisure-Time Physical Activity

\section{Figure 1}

